\title{
Odpowiedzialność za gospodarowanie środkami publicznymi w samorządach (zagadnienia prawne)
}

\section{Responsibility for the management of local governments public funds (legal issues)}

Streszczenie. Obowiązująca ustawa o odpowiedzialności za naruszenie dyscypliny finansów publicznych ma na celu eliminację niepożądanych wzorców zachowań przez możliwość orzeczenia sankcji wobec sprawcy czynu oraz realizację funkcji prewencyjnej. O tym, czy cele te są możliwe do zrealizowania, decydują m.in. szczegółowe rozwiązania zawarte w ustawie. Pamiętać również należy o zmieniającym się otoczeniu. Celem niniejszego opracowania jest wskazanie potrzeby poszerzonej debaty, na płaszczyźnie zarówno teoretycznej, jak i praktycznej, w zakresie skuteczności obowiązujących przepisów.

Słowa kluczowe: dyscyplina finansów publicznych; gospodarowanie środkami publicznymi.

\begin{abstract}
The current law on liability for breach of discipline in public finances is to eliminate undesirable behavior patterns through the possibility of a judgment sanctions against the perpetrator, as well as the implementation of the preventive.
\end{abstract}


Whether these goals are feasible decide among other things, detailed solutions contained in the Act. The aim of this study is to identify the needs of the enlarged debate, at both theoretical and practical, in terms of the effectiveness of the regulations.

Keywords: discipline of public finances; management of public funds.

\section{Wstęp}

Funkcjonująca w Polsce ustawa z dnia 17 grudnia 2004 r. o odpowiedzialności za naruszenie dyscypliny finansów publicznych ${ }^{1}$ ma na celu podnoszenie poziomu staranności dokładanej przy gospodarowaniu środkami publicznymi przez eliminację niepożądanych wzorców zachowań. Daje ona możliwość orzeczenia sankcji wobec sprawcy czynu oraz umożliwia realizację funkcji prewencyjnej ${ }^{2}$.

Celem niniejszego opracowania jest wskazanie potrzeby poszerzonej debaty, zarówno na płaszczyźnie teoretycznej, jak i praktycznej, w zakresie skuteczności obowiązujących przepisów ustawy. Rozważania w tym zakresie nabierają szczególnego znaczenia w obecnym czasie, gdy w poszukiwaniu alternatywnych pomysłów na organizację społeczeństwa i zarządzanie dobrami idea dobra wspólnego nabiera nowej dynamiki ${ }^{3}$.

Niniejszy tekst odnosi się przede wszystkim do jednostek samorządu terytorialnego i ich jednostek organizacyjnych, niemniej w przeświadczeniu autora formułowane tu wnioski mogą być przynajmniej w części odnoszone do pozostałych jednostek sektora finansów publicznych.

W pracy przyjęto, że polskie uregulowania w zakresie dyscypliny finansów publicznych uznać można za system ${ }^{4}$. W literaturze przedmiotu

Tekst jedn. Dz.U. z 2013 r., poz. 168, dalej: ustawa.

A. Talik, Dyscyplina finansów publicznych - zagadnienia wprowadzajq̨ce, „Finanse Komunalne” 2015, nr 7-8, s. 18.

3 M. Słodowa-Hełpa, Odkrywanie na nowo dobra wspólnego, „Nierówności Społeczne a Wzrost Gospodarczy” 2015, nr 3(43), s. 8-9.

4 Rozważania w tym zakresie - zob. W. Robaczyński, Odpowiedzialność za naruszenie dyscypliny finansów publicznych - wybrane zagadnienia systemowe, [w:] M. Smaga, M. Winiarz (red.), Dyscyplina finansów publicznych. Doktryna, orzecznictwo, praktyka, Warszawa 2015, s. 426-430. 
znaleźć można opinie, że przepisy ustawy są jednym z instrumentów prawnych służących racjonalizacji wydatków publicznych ${ }^{5}$. Autorowi zdecydowanie bliższy jest jednak pogląd, że służą one gospodarowaniu środkami publicznymi w sposób zgodny z określonymi w odrębnych przepisach zasadami.

Reguły określone w ustawie uznać można za rodzaj płotu odgradzającego czyny związane $\mathrm{z}$ gospodarowaniem środkami publicznymi od deliktów. Płot ten jest osadzony w polskim systemie prawnym. Zasadne jest jednak poszukiwanie odpowiedzi na szereg pytań, w tym w szczególności: czy sama konstrukcja płotu jest doskonała oraz czy właściwy obszar jest ogrodzony?

\section{Niektóre problemy obecnego systemu odpowiedzialności za naruszenie dyscypliny finansów publicznych}

Założenia konstrukcji systemu odpowiedzialności za naruszenie dyscypliny finansów publicznych przyrównać można do funkcjonującego w teorii ekonomii założenia o doskonałej konkurencji. Jest to bardziej pewien nieosiągalny cel niż rzeczywista cecha. Niewątpliwie jednak dążyć do tego celu należy.

Pod pojęciem odpowiedzialności w dyscyplinach prawniczych rozumie się zasadę ponoszenia przez podmiot przewidzianych prawem ujemnych konsekwencji za zdarzenia lub stany rzeczy podlegające ujemnej kwalifikacji normatywnej. Wyróżnia się liczne jej rodzaje, np. odpowiedzialność karną, cywilną, administracyjną, konstytucyjną, pracowniczą . Jednym z jej rodzajów jest odpowiedzialność za naruszenie dyscypliny finansów publicznych.

5 M. Gazda, O procesie racjonalizacji wydatków publicznych, „Ruch Prawniczy, Ekonomiczny i Socjologiczny” 2016, nr 1, s. 177.

$6 \quad$ J. Radzieja, Rodzaje odpowiedzialności w zwiqzzu z naruszeniem przez jednostki sektora samorzq̨dowego przepisów dotyczq̨cych wykonywania budżetu lub ich planów finansowych, „Nowe Zeszyty Samorządowe” 2016, numer specjalny, s. 22. 
Zgodnie z założeniami twórców ustawa o odpowiedzialności za naruszenie dyscypliny finansów publicznych miała mieć charakter kompleksowy. W związku z tym zrezygnowano z wcześniej funkcjonujących odesłań do innych przepisów, głównie karnych. Brak tych odesłań powoduje swoistą trudność interpretatora w przypadku, gdy zawodzi wykładnia gramatyczna $^{7}$. Co prawda brak wyraźnych odesłań nie powoduje niemożności stosowania wykładni systemowej, co możliwe jest jednak pod warunkiem właściwego umieszczenia interpretowanej regulacji.

W odniesieniu do systemu odpowiedzialności za naruszenie dyscypliny finansów publicznych brak jest zgody co do charakteru tej odpowiedzialności. W doktrynie przeważają poglądy, iż postępowanie dotyczące naruszenia dyscypliny finansów publicznych, chociaż zawiera przepisy o charakterze represyjnym, to jednak nie jest samo w sobie postępowaniem karnym. Również orzecznictwo Głównej Komisji Orzekającej oraz sądów administracyjnych nie jest spójne w tym zakresie - wskazuje się, że postępowanie to ma charakter: administracyjny, karny, dyscyplinarny, quasi--dyscyplinarny ${ }^{8}$. Kwestia ta powinna zostać jednoznacznie sprecyzowana, co znacząco podniosłoby skuteczność systemu, ponadto przynajmniej częściowo wyeliminowałoby sytuacje, w których dość podobne w swej istocie stany faktyczne kończą się zasadniczo różnymi rozstrzygnięciami. Ważnym argumentem, który należałoby uwzględnić, jest pogląd wyrażony w publikacji Państwo i My. Osiem grzechów głównych Rzeczpospolitej: „W państwie polskim legalizm systematycznie góruje nad celowością, co powoduje, że system prawny działa jak automat proceduralny, który wyklucza odpowiedzialność i blokuje rozliczalność. Przepis staje się osłoną aparatu urzędniczego przed odpowiedzialnością...”.".

7 M. Smaga, Ustawa o odpowiedzialności za naruszenie dyscypliny finansów publicznych jako ustawa kompleksowa [w:] M. Smaga, M. Winiarz, (red.), Dyscyplina finansów publicznych. Narzędzie prawidłowej gospodarki sektora publicznego, Kraków 2013, s. 283.

8 Więcej - tamże s. 277-286 oraz W. Robaczyński, Odpowiedzialność ..., s. 426-430.

9 J. Hausner, S. Mazur (red.), Państwo i My. Osiem grzechów głównych Rzeczpospolitej, Kraków 2015, s. 15. 
Kolejna kwestia budząca krytykę to rozmywanie się odpowiedzialności poprzez nieuregulowanie kwestii współsprawstwa przy skutecznym powierzeniu obowiązków i odpowiedzialności. W efekcie ustawowego niedoprecyzowania organy orzekające w bardzo różny sposób rozpatrują przedkładane im sprawy dotyczące współsprawstwa, co niewątpliwie nie może być pozytywnie ocenione przez pryzmat celów przyświecających ustawie.

Inną kwestią, która wymaga pilnego uzupełnienia, jest wprowadzenie do ustawy konstrukcji czynu ciągłego, przewidzianej w procedurze karnej. W powiązaniu bowiem ze stosunkowo krótkim okresem przedawnienia karalności czynów brak tej konstrukcji powoduje niedochodzenie karalności w odniesieniu do części sprawców czynów, w szczególności polegających na zaniechaniu. Niewątpliwie zaś osoby winne zaniechaniom nie powinny unikać odpowiedzialności tylko ze względu na budzące wątpliwości zapisy ustawowe.

Sądzę, że przedstawione powyżej rozwiązania nie są kontrowersyjne. Zdecydowanie bardziej dyskusyjna jest kwestia oceny efektywności gospodarowania środkami publicznymi za pomocą systemu odpowiedzialności za naruszenie dyscypliny finansów publicznych. Propozycje dotyczące tej kwestii pojawiają się coraz częściej. Autor w pełni podziela pogląd wyrażony przez M. Dylewskiego, że obowiązująca ustawa nie stanowi narzędzia, które zapobiega marnotrawstwu środków publicznych ${ }^{10}$. Aby jednak mogła ona wpłynąć na poprawę efektywności gospodarowania, potrzebne byłyby głębokie zmiany stanu prawnego. Autor nie jest w pełni przekonany, że system odpowiedzialności za naruszenie dyscypliny finansów publicznych jest odpowiednim instrumentem prawnym, by te cele realizować.

W odniesieniu do jednostek samorządu terytorialnego system odpowiedzialności za naruszenie dyscypliny finansów publicznych stanowi uzupełnienie kontroli sprawowanej przez obywateli/mieszkańców oraz kontroli

10 M. Dylewski, Adekwatność rozwiqzań w zakresie dyscypliny finansów publicznych a nowe trendy w gospodarce finansowej, [w:] M. Smaga, M. Winiarz (red.), Dyscyplina finansów publicznych. Doktryna..., s. 145. 
wewnętrznej w poszczególnych samorządach. Wszystkie wskazane formy kontroli są potrzebne, niemniej żadna z nich nie jest wolna od wad.

J. Stępień stwierdził, że ogromnym błędem, jaki nastąpił kilka lat po reformie samorządowej, było połączenie w jednym ręku funkcji politycznej i administracyjnej poprzez wprowadzenie jednoosobowych organów wykonawczych wybieranych w wyborach bezpośrednich. W istotny sposób ograniczyło to funkcję kontrolną organu stanowiącego i w porównaniu z pierwotnymi założeniami stanowiło wręcz wynaturzenie. Dodatkowo partie polityczne wzmocniły swój wpływ na kształt osobowy samorządu ${ }^{11}$. Podkreślił jednocześnie, że zachodni paradygmat samorządności terytorialnej, będący pierwotnym zamierzeniem założeń procesu przywracania polskiej samorządności, kładzie nacisk na „wspólnotowość, partycypacyjność obywatelską i kolegialność decyzji o charakterze politycznym i strategicznym" 12 .

J. Regulski oraz M. Kulesza po blisko dwudziestu latach po przeprowadzeniu reformy z żalem stwierdzili, że zbyt wolno następuje rozwój społeczeństwa obywatelskiego. Powinno być ono zdolne do skutecznego określania swych potrzeb oraz wyznaczania kierunków rozwoju, ale być również świadome odpowiedzialności za własne decyzje i zaniedbania ${ }^{13}$.

Opinie dotyczące kondycji, sukcesów oraz zagrożeń samorządów terytorialnych nie są zgodne, niemniej potrzeba rozwoju w nim demokracji partycypacyjnej jest niekwestionowana ${ }^{14}$.

Z przykrością stwierdzić należy, że również planowane wzmocnienie wewnętrznych systemów kontroli w jednostkach sektora finansów publicznych polegające na m.in. wprowadzeniu obligatoryjnej kontroli zarządczej nie przyniosło zamierzonych skutków. Skutki te są niewątpliwie bardzo odległe od przyświecającej ich wprowadzeniu koncepcji New Public Management. Autor w pełni podziela pogląd wyrażony w tej kwestii

11 J. Stępień, W poszukiwaniu współczesnego kształtu samorzq̨du terytorialnego, „Ruch Prawniczy, Ekonomiczny i Socjologiczny” 2015, nr 3, s. 60-61.

12 Tamże, s. 60.

13 J. Regulski, M. Kulesza, Droga do samorzqdu. Od pierwszych koncepcji do inicjatywy Senatu (1981-1989), Warszawa 2009, s. 144-145.

14 M. Słodowa-Hełpa, Rozwój zintegrowany. Warunki, wymiary, wyzwania, Warszawa 2013, s. 200. 
przez M. Jastrzębską, że: „obowiązkowe wdrożenie kontroli zarządczej w jednostkach sektora finansów publicznych [...] nie zaowocowało dotychczas pożądanymi rezultatami, gdyż w stary system wkomponowano na siłę nowe rozwiązania, czego skutkiem jest przede wszystkim nadmierny formalizm i biurokracja"15. Krytycznych opinii jest oczywiście znacznie więcej, a potrzeba poszerzonej debaty wydaje się być uzasadniona w znacznie szerszym zakresie, niż tu przedstawiono.

Mimo że różne formy kontroli wymagają przebudowy, ich rola jest niekwestionowana. Obszary związane z gospodarnością oraz efektywnością gospodarowania, ze względu na ogromną ich rolę dla kształtowania rozwoju poszczególnych społeczności, powinny być, w przekonaniu autora, oceniane zarówno przez same organy samorządu, jak i przede wszystkim przez samych mieszkańców. Ingerencja organów zewnętrznych, nawet niezależnych, nie wpisuje się bowiem w paradygmat polskiej samorządności.

\section{Uwagi końcowe}

Literatura przedmiotu i organy orzekające przedstawiają długą listę propozycji zmian ustawy o odpowiedzialności za naruszenie dyscypliny finansów publicznych - od doprecyzowania istniejących zapisów po bardzo poważne korekty o charakterze systemowym. Dla przykładu przytoczyć można, że wydany przez Główną Komisję Orzekającą numer specjalny biuletynu orzecznictwa z okazji 10 lat funkcjonowania ustawy ${ }^{16} \mathrm{w}$ trzech pierwszych artykułach zawierał w podsumowaniu następujące stwierdzenia: „Należy zatem przyjąć, że system odpowiedzialności powinien dalej ewoluować i kolejne zmiany ustawy są nieuniknione”17, „w mojej ocenie, zarówno praktyka, jak i legislatora, nasuwają się oczywiste wnioski, aby

15 M. Jastrzębska, Kontrola zarzq̨dcza czy budżet zadaniowy, „Finanse Komunalne” 2015, nr 11, s. 43.

16 Główna Komisja Orzekająca w Sprawach o Naruszenie Dyscypliny Finansów Publicznych, 10 lat ustawy o odpowiedzialności za naruszenie dyscypliny finansów publicznych, ,Biuletyn orzecznictwa w sprawach o naruszenie dyscypliny finansów publicznych” 2015, wydanie specjalne, nr 1.

17 Tamże, s. 11. 
w toku prac nad ewentualną nowelizacją ustawy rozważyć: [...]”18; „Reasumując, aktualny system dochodzenia odpowiedzialności za naruszenie dyscypliny finansów publicznych wymaga zmian"19. Zmiany postulowane są przez praktyków zajmujących się zagadnieniem (w tym członków organów orzekających i wypełniających funkcje oskarżyciela), przedstawicieli świata nauki, a także instytucje kontrolne, w tym Najwyższą Izbę Kontroli $^{20}$, oraz regionalne izby obrachunkowe ${ }^{21}$. Proponowane zmiany dotyczą zarówno przebiegu postępowania, struktury organów orzekających, zakresu podmiotowego i przedmiotowego (ze szczególnym uwzględnieniem kryterium efektywności gospodarowania środkami publicznymi), jak i rozwiązań bardzo szczegółowych (np. polegających na implementacji konstrukcji czynu ciągłego).

Wydaje się, że obowiązujący w Polsce system odpowiedzialności za naruszenie dyscypliny finansów publicznych stanowi dobre uzupełnienie kontroli sprawowanej przez obywateli i przez same jednostki gospodarujące środkami publicznymi. Sprawowany jest nie tylko przez wyspecjalizowane, ale przy tym niezawisłe i bezstronne organy. Można go uznać za posiadający pozytywny bilans doświadczeń, niemniej jego przebudowa wydaje się być nieunikniona. Wszelakie zmiany regulacyjne muszą być jednak analizowane w kontekście zintegrowanego rozwoju, który opiera się również na odpowiedzialności międzypokoleniowej i wewnątrzpokoleniowej $^{22}$.

Prawdziwym wyzwaniem stojącym przed Polską jest potrzeba głębokiej reformy zarządzania publicznego. Zmiana polegająca na wdrożeniu nie tylko postulowanych od wielu lat założeń koncepcji New Public Management, lecz również wdrożenie obligatoryjnego systemu zarządzania przez wiedzę, obligatoryjnych kryteriów doboru na stanowiska wybieralne

18 Tamże, s. 21.

19 Tamże, s. 29.

20 JST do kontroli. Prezes NIK: nadmierny jest zakres zadań i kompetencji RIO, samorzad.pap.pl, (dostęp: 12.04.2016).

21 Pismo Przewodniczącej Krajowej Rady Regionalnych Izb Obrachunkowych sygn. KRRIO-0718/II/18/2016 z dnia 24 marca 2016 r.

22 M.G. Woźniak, O ćwierćwieczu polskiej transformacji. Refleksje inicjowane pytaniami dra hab. Marcina Wojtysiak-Kotlarskiego. Część II - lekcje na przyszłość, „Nierówności Społeczne a Wzrost Gospodarczy” 2015, nr 2(42), s. 10-12. 
w systemie zarządzania publicznego, odpartyjnienie władz terenowych oraz poprawa dialogu z interesariuszami systemu ${ }^{23}$. System odpowiedzialności za naruszenie dyscypliny finansów publicznych musi być skuteczny, niemniej nie powinien on być remedium na wszystkie problemy związane z gospodarowaniem środkami publicznymi.

\section{Bibliografia:}

Dylewski M., Adekwatność rozwiqzań w zakresie dyscypliny finansów publicznych a nowe trendy w gospodarce finansowej, [w:] M. Smaga, M. Winiarz, (red.), Dyscyplina finansów publicznych. Doktryna, orzecznictwo, praktyka, C.H. Beck, Warszawa 2015.

Gazda M., O procesie racjonalizacji wydatków publicznych, „Ruch Prawniczy, Ekonomiczny i Socjologiczny” 2016, nr 1, s. 169-179.

Główna Komisja Orzekająca w Sprawach o Naruszenie Dyscypliny Finansów Publicznych, 10 lat ustawy o odpowiedzialności za naruszenie dyscypliny finansów publicznych, „Biuletyn orzecznictwa w sprawach o naruszenie dyscypliny finansów publicznych” 2015, wydanie specjalne, nr 1.

Hausner J., Mazur S. (red.), Państwo i My. Osiem grzechów głównych Rzeczpospolitej, Fundacja Gospodarki i Administracji Publicznej, Kraków 2015.

Jastrzębska M., Kontrola zarzq̨dcza czy budżet zadaniowy, „Finanse Komunalne” 2015, nr 11, s. 43.

Radzieja J., Rodzaje odpowiedzialności w zwiqzzu z naruszeniem przez jednostki sektora samorzq̨dowego przepisów dotyczq̨cych wykonywania budżetu lub ich planów finansowych, „Nowe Zeszyty Samorządowe” 2016, numer specjalny, s. 18-39.

Regulski J., Kulesza M., Droga do samorzq̨du. Od pierwszych koncepcji do inicjatywy Senatu (1981-1989), Wolters Kluwer, Warszawa 2009.

Robaczyński W., Odpowiedzialność za naruszenie dyscypliny finansów publicznych - wybrane zagadnienia systemowe, [w:] M. Smaga, M. Winiarz (red.), Dyscyplina finansów publicznych. Doktryna, orzecznictwo, praktyka, C.H. Beck, Warszawa 2015, s. 424-441.

Słodowa-Hełpa M., Odkrywanie na nowo dobra wspólnego, „Nierówności Społeczne a Wzrost Gospodarczy” 2015, nr 3(43), s. 7-24.

${ }^{23}$ Tamże s. 22. 
Słodowa-Hełpa M., Rozwój zintegrowany. Warunki, wymiary, wyzwania, CeDeWu, Warszawa 2013.

Smaga M., Ustawa o odpowiedzialności za naruszenie dyscypliny finansów publicznych jako ustawa kompleksowa, [w:] M. Smaga, M. Winiarz (red.), Dyscyplina finansów publicznych. Narzędzie prawidłowej gospodarki sektora publicznego, Publicus, Kraków 2013, s. 277-286.

Stępień J., W poszukiwaniu współczesnego kształtu samorzq̨du terytorialnego, „Ruch Prawniczy, Ekonomiczny i Socjologiczny” 2015, nr 3, s. 47-63.

Talik A., Dyscyplina finansów publicznych - zagadnienia wprowadzające, „Finanse Komunalne” 2015, nr 7-8, s. 18-29.

Woźniak M.G., O ćwierćwieczu polskiej transformacji. Refleksje inicjowane pytaniami dra hab. Marcina Wojtysiak-Kotlarskiego. Część II - lekcje na przyszłość, „Nierówności Społeczne a Wzrost Gospodarczy” 2015, nr 2(42), s. 7-25. 